\title{
Mean Platelet Volume, Platelet Distribution Width, and Platelet Count in Varicocele: A Systematic Review and Meta-Analysis
}

\author{
Jung-Soo Pyo ${ }^{\mathrm{a}}$ Won Jin Cho ${ }^{\mathrm{b}}$ \\ aDepartment of Pathology, Kangbuk Samsung Hospital, Sungkyunkwan University School of Medicine, \\ Seoul, bepartment of Urology, Chosun University Hospital, Chosun University School of Medicine, \\ Gwangju, Republic of Korea
}

\section{Key Words}

Mean platelet volume $\cdot$ Meta-analysis $\bullet$ Platelet count $\bullet$ Platelet distribution width $\bullet$ Varicocele

\begin{abstract}
Background/Aims: The aim of this study was to elucidate the usefulness of platelet indices, mean platelet volume (MPV), platelet distribution width (PDW), and platelet count in diagnosis and monitoring of varicocele. Methods: The current study included 525 patients and 379 healthy subjects from five eligible studies. We performed meta-analysis of MPV, PDW, and platelet count and mean differences in these platelet indices between healthy subjects and varicocele patients. Results: The pooled MPVs were $8.168 \mathrm{fL}$ (95\% confidence interval [CI] 7.589 to 8.747 ) and $8.801 \mathrm{fL}$ (95\% CI 8.028 to 9.574$)$ in healthy subjects and varicocele patients, respectively. The pooled mean difference in MPV between healthy subjects and varicocele patients was $0.834 \mathrm{fL}$ in case-control studies (95\% CI 0.195 to $1.473, P=0.011$ ). In both healthy subjects and varicocele patients, low platelet count subgroups showed higher MPV than high platelet count subgroups. The mean difference in MPV was higher in low platelet count subgroup. There was no significant difference in PDW between healthy subjects and varicocele patients. Conclusion: Taken together, our data showed that platelet count was significantly lower in varicocele patients than in healthy subjects. Varicocele patients showed significantly higher MPV and lower platelet count than healthy subjects. MPV levels of patients differed according to platelet counts.
\end{abstract}




\begin{tabular}{|c|c|c|}
\hline \multirow{2}{*}{$\begin{array}{l}\text { Cellular Physiology } \\
\text { and Biochemistrv }\end{array}$} & \multicolumn{2}{|c|}{ Cell Physiol Biochem 2016;38:2239-2246 } \\
\hline & $\begin{array}{l}\text { DOI: 10.1159/000445579 } \\
\text { Published online: May } 19,2016\end{array}$ & $\begin{array}{l}\text { O } 2016 \text { The Author(s). Published by S. Karger AG, Basel } \\
\text { www.karger.com/cpb }\end{array}$ \\
\hline
\end{tabular}

\section{Introduction}

The major function of platelets is to contribute to hemostasis as a component of blood. The size of platelets can impact their functions [1, 2]. Mean platelet volume (MPV) can be useful for predicting functional changes and activation of platelets [3-5]. Also, platelet distribution width (PDW) or platelet large cell ratio can be used as a platelet volume index. MPV, PDW, and other complete blood counts can be easily evaluated by routine hematological analyzers [4]. MPV is increased in various cardiovascular diseases, peripheral artery disease, and cerebrovascular disease [5-9]. In contrast, low MPV levels have been shown in some inflammatory diseases, including rheumatoid arthritis and ulcerative colitis $[4,10,11]$.

Varicocele is present in about $15 \%$ of males and represents the primary cause of male infertility in $35 \%$ of cases $[12,13]$. Moreover, varicocele is one of the surgically correctable causes of male infertility [14]. Varicocele is a mass of dilated tortuous veins of the pampiniform venous plexus of the spermatic cord. Incompetent valves of the left internal spermatic vein are involved in the pathogenesis of varicocele and can lead poor drainage and progressive dilatation and elongation. Thus, varicocele induces hypoxia of the testicular tissues by the destruction of the one way valves in the internal spermatic veins. In addition, previous studies have reported that systemic vascular viscosity was correlated with varicocele [15, 16]. Microscopic examination of varicocele shows vascular wall thickening, segmental obliteration, medial hypertrophy of longitudinal smooth muscle fibers, fragmentation of the internal elastic lamina, and occasional occlusive thrombi [17]. Vascular change and platelet indices might be useful for detection or screening of subclinical varicocele.

In the present meta-analysis, we investigated MPV, PDW, and platelet count in varicocele patients and healthy subjects in eligible studies. In addition, a systematic review and metaanalysis, including subgroup analysis based on platelet count, was performed to elucidate mean values and mean differences in MPV, PDW, and platelet count between varicocele patients and healthy subjects.

\section{Materials and Methods}

Published study search and selection criteria

Relevant articles were obtained by searching the PubMed and MEDLINE databases through February 29, 2016. The search was performed using the following key words: 'mean platelet volume, platelet distribution width, or platelet count' and 'varicocele.' The titles and abstracts of all returned articles were screened for exclusion. Review articles were also screened to identify additional eligible studies. The search results were then reviewed according to the following inclusion and exclusion criteria: (1) MPV, PDW, or platelet count investigated in human varicocele patients, (2) case reports or non-original articles were excluded, and (3) non-English language publications were excluded.

\section{Data extraction}

The following information was collected from the full texts of eligible studies and was verified: first author's name, publication year, study location, number of patients analyzed, mean value and standard deviation of MPV, platelet distribution width, and platelet count. We did not define a minimum number of patients for inclusion in our study. Any disagreements were resolved by consensus.

\section{Statistical analysis}

All data were analyzed using the Comprehensive Meta-Analysis software package (Biostat, Englewood, NJ, US). We investigated MPV, PDW, and platelet count in healthy subjects and varicocele patients. Metaanalysis was performed on mean values of MPV, PDW, and platelet count and mean differences in MPV, PDW, and platelet count between healthy subjects and pre-treated varicocele patients. A fixed effect metaanalysis estimates a single effect that is assumed to be common to every study, while a random effects metaanalysis estimates the mean of a distribution of effects. Although the present meta-analysis was performed using the fixed and random effect models, the values pooled using a random effect model were utilized for 


\section{Cellular Physiology Cell Physiol Biochem 2016;38:2239-2246 and Biochemistry Published online: May 19, $2016 \quad \begin{aligned} & \text { DOI: 10.1159/000445579 } 2016 \text { The Author(s). Published by S. Karger AG, Basel } \\ & \text { www.karger.com/cpb }\end{aligned}$ \\ Pyo/Cho: Role of Platelet Indices in Varicocele}

interpretation. The heterogeneity between studies was assessed using $\mathrm{Q}$ and $I^{2}$ statistics and calculated $P$-values. A sensitivity analysis was conducted to assess the heterogeneity of eligible studies and the impact of each study on the combined effect. Subgroup analysis based on platelet count was performed for mean values and mean differences in MPV and PDW. To identify any publication bias, Begg's funnel plot and Egger's test were performed. The results were considered statistically significant at $P<0.05$.

\section{Results}

Selection and characteristics of studies

In the present study, 13 reports were identified in the database search. Of these, 8 reports were excluded due to lack of sufficient information. After applying the inclusion and exclusion criteria, 5 reports were finally selected for inclusion in the meta-analysis (Fig.1 and Table 1) $[13,14,18-20]$. The current study included 10 subsets of 5 eligible studies. Because Camoglio's report was subdivided into subgroups with and without testicular hypertrophy [20], 6 subsets included in patient group. In healthy subject group, 4 subsets were included from four eligible studies. The main characteristics of the eligible studies are shown in Table 1. In eligible studies, platelet count ranged from 219 to $243\left(\mathrm{x} 10^{3} / \mu \mathrm{L}\right)$ and from 223 to $258\left(\times 10^{3} / \mu \mathrm{L}\right)$ in varicocele patients and healthy subjects, respectively. PDW ranged from $13.90 \mathrm{fL}$ to $17.41 \mathrm{fL}$ and from $12.60 \mathrm{fL}$ to $17.85 \mathrm{fL}$ in varicocele patients and healthy subjects, respectively.

Fig. 1. Flow chart of the study search and selection methods.

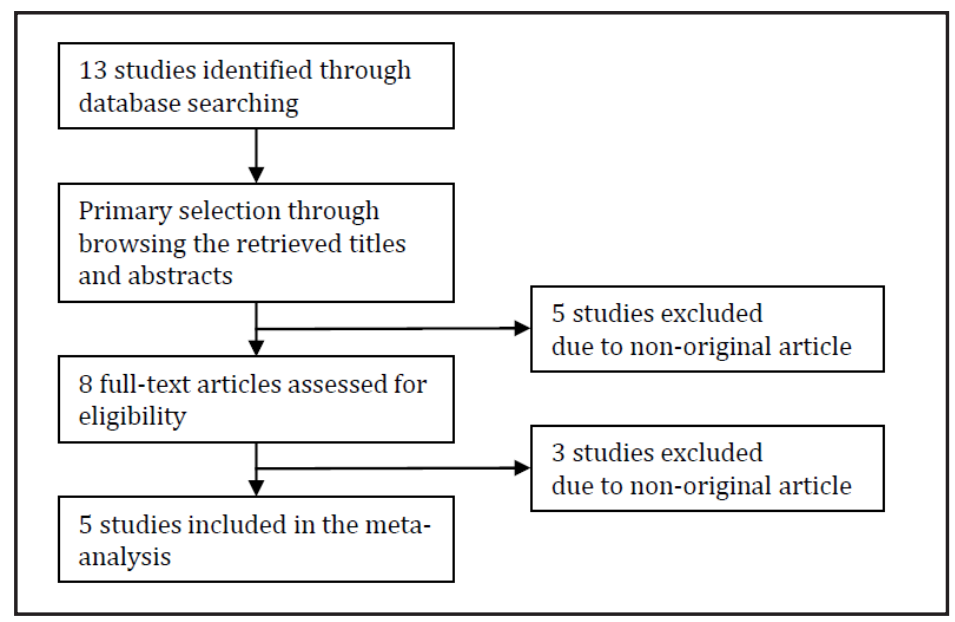

Table 1. Main characteristics of eligible studies

\begin{tabular}{|c|c|c|c|c|c|c|c|c|c|}
\hline \multirow{3}{*}{ Study } & \multirow{3}{*}{ Location } & \multicolumn{5}{|c|}{ Patients } & \multicolumn{3}{|c|}{ Healthy subjects } \\
\hline & & \multicolumn{3}{|c|}{ MPV (fL) } & \multirow{2}{*}{$\begin{array}{l}\text { PDW } \\
\text { (fL) }\end{array}$} & \multirow{2}{*}{$\begin{array}{c}\text { Platelet } \\
\text { count } \\
\left(\mathrm{x} 10^{3} / \mu \mathrm{L}\right)\end{array}$} & \multirow[b]{2}{*}{$\mathrm{N}$} & \multirow{2}{*}{ 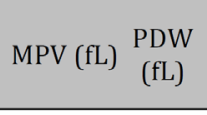 } & \multirow{2}{*}{$\begin{array}{c}\text { Platelet } \\
\text { count } \\
\left(\mathrm{x} 10^{3} / \mu \mathrm{L}\right)\end{array}$} \\
\hline & & $\mathrm{N}$ & $\begin{array}{l}\text { Pre- } \\
\text { treated }\end{array}$ & $\begin{array}{l}\text { Post- } \\
\text { treated }\end{array}$ & & & & & \\
\hline Bozkurt 2012 [18] & Turkey & 60 & $9.89 \pm 1.58$ & & & 219 & 57 & $7.97 \pm 0.88$ & 231 \\
\hline Camoglio 2015 [20] & Italy & & & & & & & & \\
\hline $\begin{array}{l}\text { without testicular } \\
\text { hypertrophy }\end{array}$ & & 47 & $8.4 \pm 0.9$ & & & & 52 & $7.6 \pm 0.9$ & \\
\hline $\begin{array}{l}\text { with testicular } \\
\text { hypertrophy }\end{array}$ & & 46 & $7.6 \pm 0.8$ & & & & & & \\
\hline Coban 2015 [13] & Turkey & 57 & $8.33 \pm 0.99$ & $8.10 \pm 1.09$ & 16.88 & 242 & & & \\
\hline Coban 2015 [19] & Turkey & 264 & $8.52 \pm 4.96$ & & 17.41 & 243 & $220^{\circ}$ & $7.84 \pm 1.0317 .85$ & 258 \\
\hline $\begin{array}{l}\text { Mahdavi-Zafarghandi } 2014 \\
\text { [14] }\end{array}$ & Iran & 511 & $10.10 \pm 1.30$ & & 13.90 & 224 & 50 & $9.30 \pm 1.1012 .60$ & 223 \\
\hline
\end{tabular}

MPV, Mean platelet volume; N, Number of patients or healthy subjects; PDW, Platelet distribution width 


\section{Cellular Physiology Cell Physiol Biochem 2016;38:2239-2246 \begin{tabular}{l|l} 
and Biochemistry & DOI: 10.1159/000445579 \\
Published online: May 19, 2016 & $\begin{array}{l}\text { C } 2016 \text { The Author(s). Published by S. Karger AG, Basel } \\
\text { www.karger.com/cpb }\end{array}$
\end{tabular} \\ Pyo/Cho: Role of Platelet Indices in Varicocele}

Table 2. Meta-analysis for mean platelet volume, platelet count and platelet distribution width. CI, Confidence interval

\begin{tabular}{lcccccc}
\hline & $\begin{array}{c}\text { Number Number } \\
\text { of } \\
\text { subsets patients }\end{array}$ & $\begin{array}{c}\text { Fixed effect } \\
{[95 \% \mathrm{CI}]}\end{array}$ & $\begin{array}{c}\text { Heterogeneity test } \\
{[P \text {-value }]}\end{array}$ & $\begin{array}{c}\text { Random effect } \\
{[95 \% \mathrm{CI}]}\end{array}$ & $\begin{array}{c}\text { Egger's } \\
\text { Test }\end{array}$ \\
\hline $\begin{array}{l}\text { Mean platelet volume }(\mathrm{fL}) \\
\quad\end{array}$ & 4 & 379 & $7.981[7.881,8.081]$ & $<0.001$ & $8.168[7.589,8.747]$ & 0.418 \\
Healthy subjects & 6 & 525 & $8.806[8.383,8.629]$ & $<0.001$ & $8.801[8.028,9.574]$ & 0.193
\end{tabular}

Platelet distribution width (fL)

\begin{tabular}{lllllll} 
Healthy subjects & 2 & 270 & $17.65[17.52,17.78]$ & 1.000 & $15.24[10.09,20.38]$ & - \\
$\quad$ Varicocele & 3 & 372 & $17.08[16.89,17.27]$ & 0.001 & $16.09[14.28,17.90] 0.359$ \\
& & & & & & \\
& & & & & & \\
$\begin{array}{l}\text { Platelet count }\left(\mathrm{x} 10^{3} / \mu \mathrm{L}\right) \\
\quad \text { Healthy subjects }\end{array}$ & 3 & 327 & $247.4[240.8,254.1]$ & $<0.001$ & $238.1[213.6,262.5]$ & 0.703 \\
$\quad$ Varicocele & 4 & 432 & $233.7[229.4,238.0]$ & $<0.001$ & $231.9[218.0,245.7]$ & 0.662 \\
\hline
\end{tabular}

Table 3. Subgroup analysis based on platelet count for mean platelet volume between healthy subjects and variococele patients. CI, Confidence interval; PLT, Platelet

\begin{tabular}{|c|c|c|c|c|c|c|}
\hline & \multirow{2}{*}{\multicolumn{2}{|c|}{$\begin{array}{l}\text { Number Number } \\
\text { of of } \\
\text { studies patients }\end{array}$}} & \multicolumn{4}{|c|}{ Mean platelet volume } \\
\hline & & & $\begin{array}{c}\text { Fixed effect } \\
{[95 \% \mathrm{CI}]}\end{array}$ & $\begin{array}{c}\text { Heterogeneity test } \\
{[P \text {-value }]}\end{array}$ & $\begin{array}{c}\text { Random effect } \\
{[95 \% \mathrm{CI}]}\end{array}$ & $\begin{array}{l}\text { Egger's } \\
\text { Test }\end{array}$ \\
\hline Healthy subjects & 3 & 327 & $8.057[7.984,8.166]$ & $<0.001$ & $8.359[7.603,9.116]$ & 0.352 \\
\hline $\begin{array}{l}\text { Low PLT count } \\
\left(<233 \times 10^{3} / \mu \mathrm{L}\right)\end{array}$ & 2 & 107 & $8.448[8.265,8.631]$ & $<0.001$ & $8.631[7.328,9.934]$ & - \\
\hline $\begin{array}{l}\text { High PLT count } \\
\left(\geq 233 \times 10^{3} / \mu \mathrm{L}\right)\end{array}$ & 1 & 220 & $7.840[7.704,7.976]$ & 1.000 & $7.840[7.704,7.976]$ & - \\
\hline Varicocele patients & 4 & 432 & $9.085[8.908,9.262]$ & $<0.001$ & $9.215[8.227,10.203]$ & 0.627 \\
\hline $\begin{array}{l}\text { Low PLT count } \\
\left(<233 \times 10^{3} / \mu \mathrm{L}\right)\end{array}$ & 2 & 111 & $10.007[9.741,10.273]$ & 0.442 & $10.007[9.741,10.273]$ & - \\
\hline $\begin{array}{l}\text { High PLT count } \\
\left(\geq 233 \times 10^{3} / \mu \mathrm{L}\right)\end{array}$ & 2 & 321 & $8.360[8.123,8.596]$ & 0.567 & $8.360[8.123,8.596]$ & - \\
\hline
\end{tabular}

Mean values of MPV, PDW, and platelet count

To evaluate the mean values of platelet indices in varicocele patients, we performed meta-analysis of MPV, PDW, and platelet count in healthy subjects and varicocele patients. The pooled MPV was higher in varicocele patients than in healthy subjects $(8.801 \mathrm{fL}, 95 \%$ CI 8.028 to 9.574 vs. $8.168 \mathrm{fL}, 95 \%$ CI 7.589 to 8.747 , Table 2). In sensitivity analysis, eligible studies had no effect on the pooled MPVs in healthy subjects (range: 7.812 to 8.359 ) or varicocele patients (range: 8.536 to 9.048). There was no significant publication bias according to Egger's test ( $P=0.418$ and $P=0.193$, respectively) and Begg's funnel plots of healthy subjects and varicocele patients. The pooled PDW was $15.24 \mathrm{fL}$ (95\% CI 10.09 to 20.38 ) and $16.09 \mathrm{fL}$ (95\% CI 14.28 to 17.90$)$ in healthy subjects and varicocele patients, respectively. In addition, the pooled platelet counts of healthy subjects and varicocele patients were $238.1 \times 10^{3} / \mu \mathrm{L}(95 \%$ CI 213.6 to 262.5$)$ and $231.9 \times 10^{3} / \mu \mathrm{L}(95 \%$ CI 218.0 to 245.7), respectively.

\section{Subgroup analysis}

To elucidate the impact of platelet count on MPV, subgroup analysis was performed based on platelet count. For subgroup analysis, the criterion dividing groups into high and low platelet count subgroups was determined as the median value of platelet counts of 


\begin{tabular}{|c|c|c|}
\hline \multirow{2}{*}{$\begin{array}{l}\text { Cellular Physiology } \\
\text { and Biochemistrv }\end{array}$} & \multicolumn{2}{|c|}{ Cell Physiol Biochem 2016;38:2239-2246 } \\
\hline & $\begin{array}{l}\text { DOI: 10.1159/000445579 } \\
\text { Published online: May } 19,2016\end{array}$ & $\begin{array}{l}\text { O } 2016 \text { The Author(s). Published by S. Karger AG, Basel } \\
\text { www.karger.com/cpb }\end{array}$ \\
\hline
\end{tabular}

Table 4. Mean difference of mean platelet volume, platelet count and platelet distribution width between healthy subjects and varicocele patients. CI, Confidence interval; PLT, Platelet

\begin{tabular}{|c|c|c|c|c|}
\hline & \multicolumn{4}{|c|}{ Mean difference between varicocele patients and healthy subjects } \\
\hline & $\begin{array}{c}\text { Fixed effect } \\
{[95 \% \mathrm{CI}]}\end{array}$ & $\begin{array}{c}\text { Heterogeneity test } \\
{[P \text {-value }]}\end{array}$ & $\begin{array}{c}\text { Random effect } \\
{[95 \% \mathrm{CI}]}\end{array}$ & $\begin{array}{c}\text { Egger's } \\
\text { Test }\end{array}$ \\
\hline Mean platelet volume (fL) & $0.725[0.536,0.914]$ & $<0.001$ & $0.834[0.195,1.473]$ & 0.467 \\
\hline $\begin{array}{l}\text { Low PLT count } \\
\left(<233 \times 10^{3} / \mu \mathrm{L}\right)\end{array}$ & $1.364[1.033,1.695]$ & 0.001 & $1.360[0.263,2.458]$ & - \\
\hline $\begin{array}{l}\text { High PLT count } \\
\left(\geq 233 \times 10^{3} / \mu \mathrm{L}\right)\end{array}$ & $0.680[0.013,1.347]$ & 1.000 & $0.680[0.013,1.347]$ & - \\
\hline Platelet distribution width (fL) & $-0.32[-0.57,-0.07]$ & 0.001 & $0.37[-1.33,2.07]$ & - \\
\hline $\begin{array}{l}\text { Low PLT count } \\
\left(<233 \times 10^{3} / \mu \mathrm{L}\right)\end{array}$ & $1.30[0.34,2.26]$ & 1.000 & $1.30[0.34,2.26]$ & - \\
\hline $\begin{array}{l}\text { High PLT count } \\
\left(\geq 233 \times 10^{3} / \mu \mathrm{L}\right)\end{array}$ & $-0.44[-0.70,-0.18]$ & 1.000 & $-0.44[-0.70,-0.18]$ & - \\
\hline Platelet count $\left(\mathrm{x} 10^{3} / \mu \mathrm{L}\right)$ & $-11.99[-20.14,-3.84]$ & 0.375 & $-11.99[-20.14,-3.84]$ & 0.479 \\
\hline
\end{tabular}

patients $\left(233 \times 10^{3} / \mu \mathrm{L}\right)$. In both healthy subjects and varicocele patients, the pooled MPVs were higher in low platelet count subgroups than in high platelet count subgroups. The pooled MPV of healthy subjects was $8.631 \mathrm{fL}$ (95\% CI 7.328 to 9.934$)$ and $7.840 \mathrm{fL} \mathrm{(95 \%} \mathrm{CI}$ 7.704 to 7.946 ) in low and high platelet count subgroups, respectively. In varicocele patients, the pooled MPV was $10.007 \mathrm{fL}$ (95\% CI 9.741 to 10.273) and $8.360 \mathrm{fL}$ (95\% CI 8.123 to 8.596 ) in low and high platelet count subgroups, respectively (Table 3).

Mean differences in MPV, PDW, and platelet count

Next, we performed meta-analysis of mean differences in MPV, PDW, and platelet count between varicocele patients and healthy subjects. The pooled mean difference in MPV was $0.834(95 \%$ CI 0.195 to $1.473, P=0.011)$ in the random effect models (Table 4$)$. The mean difference in MPV was higher in low platelet count subgroups than in high platelet count subgroups $(1.360,95 \%$ CI 0.263 to $2.458, P=0.015$ vs. $0.680,95 \%$ CI 0.013 to $1.347, P$ $=0.046$, respectively). The pooled mean differences in PDW and platelet count were 0.37 (95\% CI -1.33 to $2.07, P=0.673$ ) and $-11.99(95 \%$ CI -20.14 to $-3.84, P=0.004)$, respectively.

\section{Discussion}

It is known that increased pressure in the pampiniform venous plexus and venous drainage are involved in the pathogenesis of varicocele. These occurrences lead to dilatation of the veins of the pampiniform plexus and to subsequent vascular damages. However, the role of platelets in the pathogenesis of varicocele is not fully understood. The current study is the first meta-analysis of published studies on the roles of MPV in varicocele and shows four major findings. First, there was a significant difference in MPV between varicocele patients and healthy subjects. Second, platelet count was significantly lower in varicocele patients than in healthy subjects. Third, there was no significant difference in PDW between varicocele patients and healthy subjects. Fourth, varicocele patients with low platelet count showed higher MPV level than patients with high platelet count.

Although the pathogenesis of varicocele has not been fully elucidated, various vascular changes, including vascular wall thickening, segmental obliteration, fragmentation of the internal elastic lamina, and occasional occlusive thrombi, have been microscopically identified [17]. In addition, a systemic vascular varicosity has been positively correlated 


\section{Cellular Physiology Cell Physiol Biochem 2016;38:2239-2246

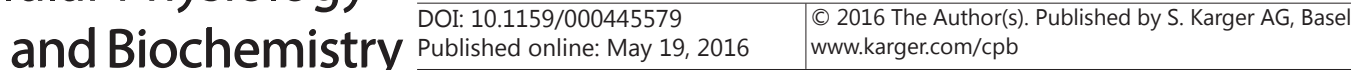 \\ Pyo/Cho: Role of Platelet Indices in Varicocele}

with varicocele $[15,16]$. Changes in platelet function, induced by vascular damage, could be associated with varicocele. MPV reflects functional changes and activation of platelets according to average platelet size [3-5]. Although platelet aggregation could be a specific test for platelet function [21, 22], the diagnostic roles of platelet indices, such as MPV and PDW, have been recently introduced in various disease including varicocele. Nevertheless, the correlations between pathogenesis of varicocele and platelet indices have not yet been fully elucidated, and MPV could be useful for diagnosis or monitoring of varicocele.

Varicoceles are most frequently diagnosed before 30 years of age and occur in 15-20\% of all males. Although varicocele is basically diagnosed through physical examination and/ or color Doppler ultrasonography, little is known regarding the pre-operative and postoperative monitoring hematologic modalities for diagnosis and monitoring of varicocele patients, including subclinical status. Platelet indices have the common advantage that they can be routinely evaluated using hematological analyzers. Among these indices, high MPV has been identified in various benign diseases and malignant tumors. In the present metaanalysis, MPV of varicocele patients was significantly higher than that in healthy subjects (mean difference $0.834,95 \%$ CI 0.195 to 1.473 ). In addition, MPV has been shown to be increased by varicocele grading [18] and decreased by surgery [13]. Consequently, MPV might be a candidate for diagnosis or monitoring of varicocele in daily practice. In our data, the ranges of MPV in varicocele patients and healthy subjects were 7.60 to $10.10 \mathrm{fL}$ and 7.60 to $9.30 \mathrm{fL}$, respectively. Because these values overlapped and the included studies were evaluated in limited geographic areas, the interpretation of MPV level in varicocele patients is limited. The possible causes for overlapped MPV values might be associated with study location, race, age, patient condition, and so on. Thus, meta-analysis of the mean differences in MPV between varicocele patients and healthy subjects is required. In addition, subgroup analysis based on various factors, including patient age, could be helpful for understanding the MPV levels of varicocele patients.

Little is known as to whether platelet count affects MPV and PDW in varicocele patients. Patients with varicocele showed significantly lower platelet count and higher MPV than healthy subjects. Interestingly, varicocele patients with high platelet count showed lower MPV level than healthy subjects with high platelet count (Table 3). However, the mean differences in MPV between varicocele patients and healthy subjects were 1.360 (95\% CI 0.263 to $2.458, P=0.015$ ) and 0.680 (95\% CI 0.013 to $1.347, P=0.046)$ in low and high platelet count subgroups, respectively. Our data showed that MPV in varicocele patients was significantly higher than that in healthy subjects, regardless of platelet count. Calculating of $\mathrm{MPV} /$ platelet count ratio would be useful for interpretation of the impact on MPV. However, the current study could not perform the test for MPV/platelet count ratio due to insufficient information. There was no difference in PDW between varicocele patients and healthy subjects; however, subgroups with low platelet count showed significantly higher PDW than high platelet count subgroups. For application of MPV or PDW in varicocele, platelet count of patients should be considered, and more detailed information is needed.

There are a number of limitations in the current study. First, Coban et al. have reported that MPV was significantly decreased after surgery [13]. The present study could not analyze the correlation between post-operative and pre-operative patients and healthy subjects due to insufficient information in the original studies. Second, in subgroup analysis based on platelet count, MPV was higher in low platelet count subgroups than in high platelet count subgroups. However, we could not explain the correlation between platelet count and MPV in the current study. Third, as described above, high MPV level is identified in various diseases, including vascular disorders. Although MPV increases in varicocele and positively correlates with varicocele grade, there may be a limitation to its application in screening of varicocele in the general population. Fourth, Demirin et al. have reported an MPV value of $8.9 \pm 1.4 \mathrm{fL}$ (95\% CI 7.2 to 11.7 ) in 326 healthy subjects [23]. In our meta-analysis, the pooled MPV of male samples was $8.359 \mathrm{fL}$ ( $95 \%$ CI 7.603 to 9.116). In our unpublished data, the pooled MPV of overall healthy subjects and female samples was $8.428 \mathrm{fL}$ (95\% CI 8.118 to 8.738) and 8.674 (95\% CI 8.076 to 9.273), respectively. In addition, the normal range of MPV in 


\section{Cellular Physiology Cell Physiol Biochem 2016;38:2239-2246 \begin{tabular}{c|c} 
DOI: 10.1159/000445579 & $\begin{array}{l}\text { O } 2016 \text { The Author(s). Published by S. Karger AG, Basel } \\
\text { www.karger.com/cpb }\end{array}$ \\
\cline { 2 - 3 } & and Biochemished online: May 19, 2016
\end{tabular} \\ Pyo/Cho: Role of Platelet Indices in Varicocele}

males should first be elucidated in order to evaluate the usefulness of MPV as a monitoring or diagnostic parameter.

In conclusion, our results showed that MPV was significantly higher in varicocele patients than in healthy subjects. Moreover, low platelet count was associated with high MPV level. Further cumulative studies of varicocele will be required before application of MPV in diagnosis or monitoring.

\section{Acknowledgements}

This study was supported by research fund from Chosun University, 2014.

\section{Disclosure Statement}

The authors declare that they have no conflict of interest.

\section{References}

1 Mangalpally KK, Siqueiros-Garcia A, Vaduganathan M, Dong JF, Kleiman NS, Guthikonda SJ: Platelet activation patterns in platelet size sub-populations: differential responses to aspirin in vitro. J Thromb Thrombolysis 2010;30:251-262.

2 Honisch S, Gu S, Vom Hagen JM, Alkahtani S, Al Kahtane AA, Tsapara A, Hermann A, Storch A, Schöls L, Lang F, Stournaras C. Chorein Sensitive Arrangement of Cytoskeletal Architecture. Cell Physiol Biochem 2015;37:399-408.

3 Kai H, Kitadai Y, Kodama M, Cho S, Kuroda T, Ito M, Tanaka S, Ohmoto Y, Chayama K: Involvement of proinflammatory cytokines IL-1beta and IL-6 in progression of human gastric carcinoma. Anticancer Res 2005;25:709-713.

4 Gasparyan AY, Ayvazyan L, Mikhailidis DP, Kitas GD: Mean platelet volume: a link between thrombosis and inflammation? Curr Pharm Des 2011;17:47-58.

5 Mutlu H, Artis TA, Erden A, Akca Z: Alteration in mean platelet volume and platicrit values in patients with cancer that developed thrombosis. Clin Appl Thromb Hemost 2013;19:331-333.

6 Muscari A, Puddu GM, Cenni A, Silvestri MG, Giuzio R, Rosati M, Santoro N, Bianchi G, Magalotti D, Zoli M: Mean platelet volume (MPV) increase during acute non-lacunar ischemic strokes. Thromb Res 2009;123:587-591.

7 Berger JS, Eraso LH, Xie D, Sha D, Mohler ER 3rd: Mean platelet volume and prevalence of peripheral artery disease, the National Health and Nutrition Examination Survey, 1999-2004. Atherosclerosis 2010;213:586591.

8 Chu SG, Becker RC, Berger PB, Bhatt DL, Eikelboom JW, Konkle B, Mohler ER, Reilly MP, Berger JS: Mean platelet volume as a predictor of cardiovascular risk: a systematic review and meta-analysis. J Thromb Haemost 2010;8:148-156.

9 Xia W, Li Y, Wang B, Chen J, Wang X, Sun Q, Sun F, Li Z, Zhao Z. Enhanced Store-Operated Calcium Entry in Platelets is Associated with Peripheral Artery Disease in Type 2 Diabetes. Cell Physiol Biochem 2015;37:1945-1955.

10 Kisacik B, Tufan A, Kalyoncu U, Karadag O, Akdogan A, Ozturk MA, Kiraz S, Ertenli I, Calguneri M: Mean platelet volume (MPV) as an inflammatory marker in ankylosing spondylitis and rheumatoid arthritis. Joint Bone Spine 2008;75:291-294.

11 Yüksel O, Helvaci K, Başar O, Köklü S, Caner S, Helvaci N, Abayli E, Altiparmak E: An overlooked indicator of disease activity in ulcerative colitis: mean platelet volume. Platelets 2009;20:277-281.

12 Goldstein M: Surgical management of male infertility. Campbell-Walsh Urology. 10th ed. Elsevier Saunders, Philadelphia, PA, 2012.

13 Coban S, Keleș I, Biyik I, Güzelsoy M, Türkoğlu AR, Ocak N: Does varicocele correction lead to normalization of preoperatively elevated mean platelet volume levels? Can Urol Assoc J 2015; 9:E5-9. 


\section{Cellular Physiology Cell Physiol Biochem 2016;38:2239-2246 \begin{tabular}{l|l} 
DOI: 10.1159/000445579 & $\begin{array}{l}\text { O 2016 The Author(s). Published by S. Karger AG, Basel } \\
\text { www.karger.com/cpb }\end{array}$
\end{tabular} \\ Pyo/Cho: Role of Platelet Indices in Varicocele}

14 Mahdavi-Zafarghandi R, Shakiba B, Keramati MR, Tavakkoli M: Platelet volume indices in patients with varicocele. Clin Exp Reprod Med 2014;41:92-95.

15 Kiliç S, Aksoy Y, Sincer I, Oğuz F, Erdil N, Yetkin E: Cardiovascular evaluation of young patients with varicocele. Fertil Steril 2007;88:369-373.

16 Yetkin E, Kilic S, Acikgoz N, Ergin H, Aksoy Y, Sincer I, Aktürk E, Beytur A, Sivri N, Turhan H: Increased prevalence of varicocele in patients with coronary artery ectasia. Coron Artery Dis 2005;16:261-264.

17 Bostwick DG, Cheng L: Urologic surgical pathology. 2nd ed. Mosby Elsevier, 2008.

18 Bozkurt Y, Soylemez H, Sancaktutar AA, Islamoglu Y, Kar A, Penbegul N, Atar M, Bodakci MN, Hatipoglu NK: Relationship between mean platelet volume and varicocele: a preliminary study. Urology 2012;79:10481051.

19 Çoban S, Keleş I, Biyik I, Güzelsoy M, Türkoğlu AR, Özgünay T, Ocak N: Is there any relationship between mean platelet volume and varicocele? Andrologia 2015;47:37-41.

20 Camoglio FS, Peretti M, Bianchi F, Mariotto A, Zampieri N. Mean platelet volume and varicocele: comparison between adolescents and adults. Am J Clin Exp Urol 2015;3:100-106.

21 Beyan C, Beyan E. Mean platelet volume may not be related to the physiopathology of varicocele. Andrologia 2015;47:367.

22 Beyan C, Kaptan K, Ifran A. Platelet count, mean platelet volume, platelet distribution width, and plateletcrit do not correlate with optical platelet aggregation responses in healthy volunteers. J Thromb Thrombolysis 2006;22:161-164.

23 Demirin H, Ozhan H, Ucgun T, Celer A, Bulur S, Cil H, Gunes C, Yildirim HA: Normal range of mean platelet volume in healthy subjects: Insight from a large epidemiologic study. Thromb Res 2011;128:358-360. 